\title{
Management of the Egyptian alfalfa weevil, Hypera brunneipennis (Boheman) (Coleoptera: Curculionidae), in the alfalfa, Medicago sativa $L$., using the entomopathogenic fungus, Beauveria bassiana (Balsamo) Vuillemin
}

\author{
Monir M. M. El Husseini(D)
}

\begin{abstract}
Larval and adult populations of the Egyptian alfalfa weevil (EAW) Hypera brunneipennis (Boheman) (Coleoptera: Curculionidae) was monitored after application of the entomopathogenic fungus Beauveria bassiana in the alfalfa field (Medicago sativa L.) in two successive seasons 2014/2015 and 2015/2016. The second and last generation of the weevil on April 10,2016, was controlled by only one application with the conidiospores of the entomopathogenic fungus B. bassiana $\left(3 \times 10^{8}\right.$ spores $\left./ \mathrm{ml}\right)$. Accordingly, the larval population decreased from $16.07 \pm 1.09$ in season 2015/ 2016 to $7.37 \pm 0.05$ individuals/50 sweep net double strokes in season 2016/2017. Also, the adult weevil's population decreased from $5.66 \pm 0.8$ to $2.55 \pm 0.6$ individuals $/ 50$ sweep net double strokes in the two seasons, respectively. $39.66 \%$ mortality rate was recorded in the Hypera brunneipennis adults aestivated under loose bark of the surrounding eucalyptus trees, which received the application of B. bassiana in the field. Another application with the fungus, targeting the second generation of the pest adults in alfalfa each season, will undoubtedly lead to a further decrease in the pest population.
\end{abstract}

Keywords: Beauveria bassiana, Hypera brunneipennis, Alfalfa, Biological control

\section{Background}

The Egyptian alfalfa weevil (EAW), Hypera brunneipennis (Boheman) (Col.: Curculionidae), is considered one of the most damaging economic insect pests attacking the Egyptian clover, Trifolium alexandrinum L., and alfalfa, Medicago sativa L., in Egypt. Population abundance of EAW in clover fields of Egypt was reported by different authors, and it was present all over the season beginning from December to May (El Sherif et al. 1978; El-Mezayyen 2001; ElMezayyen 2003; Rakha 2008, and Awadalla et al. 2014). The larvae and adults of the weevil are feeding on the foliage of alfalfa and clover, but the larvae cause more damage.

Correspondence: monir.elhusseini@agr.cu.edu.eg;

monirelhusseini45@gmail.com

Centre of Biological Control, Faculty of Agriculture, Cairo University, Giza, Egypt
They prefer to feed on the young leaves. Adults generally feed on the leaf margins (Rakha 2008; Baysal et al. 2018). The young larval instars feed on the plant terminals, and the older ones feed on the leaflets. Under high infestation, the plants could completely be defoliated. Symptoms of infestation appear in winter/spring, especially in alfalfa and clover areas at field edges adjacent to eucalyptus and date palm trees (adult weevil aestivating sites). This pest is found in all alfalfa-producing areas worldwide (Cook et al. 2004; Atanasova 2012). Leguminous crops are its host plants (Summers et al. 1975; Al-Azawi et al. 1986; Fouad et al. 2012; Awadalla et al. 2014). The EAW generally has one generation per year in South Europe and North America. In recent years, it has evolved from a univoltine (one generation per year) into a multivoltine (several generations per year) insect. Rather than leaving the field for aestivation,
Springer Open

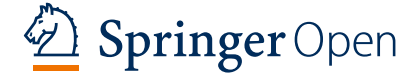

(c) The Author(s). 2019 Open Access This article is distributed under the terms of the Creative Commons Attribution 4.0 International License (http://creativecommons.org/licenses/by/4.0/), which permits unrestricted use, distribution, and reproduction in any medium, provided you give appropriate credit to the original author(s) and the source, provide a link to the Creative Commons license, and indicate if changes were made. 
some adults remain in the alfalfa, mate and continue to lay eggs. These eggs soon hatch, giving rise to a second generation of weevil larvae that continue to cause damage to the second and sometimes third cuttings (Cook et al. 2004).

As forage crop, alfalfa and clover fields in Egypt are not treated with chemical insecticides, except after seed germination, when plantlets were severely attacked by the cotton leaf worm, Spodoptera littoralis (Boisd.) before re-sowing the crop again. Generally, no control actions are needed to control the EAW in the Egyptian clover ( $T$. alexandrinum) in Egypt because the farmers tolerate its damage in the crop among the season and avoid using insecticides on this important forage crop for their farm animals (EL-Husseini 1981). Also, the weevil larvae present on the plants are removed by the first and the next successive cuttings. In case of M. sativum that remains growing in the field for few successive years, the damage caused by EAW adults and larvae increases year after year, and sometimes, there are necessitates to control action (Cook et al. 2004).

In such an important forage crop for farm animals with no use of chemical insecticides, the biological control is the alternative for controlling its insect pests, especially the microbial control with entomopathogenic viruses, bacteria and fungi. The use of entomopathogenic fungi (EPF) in biological control of insect pests has become of immense significance due to their environmental and food safety concerns (Reddy et al. 2016; Mascarin and Jaronski 2016). Species of the genera Beauveria, Metarhizium, Lecanicillium and Isaria are commercially produced (Vega et al. 2009). B. bassiana was reported to infect 707 species of insect hosts, including 521 genera and 149 families of 15 insect orders (Imoulan et al. 2017). B. bassiana was successfully applied against various insect pests worldwide, e.g., Bemesia tabaci (Mascarin et al. 2013), Nilaparvata lugens (Rombach et al. 1986) and Anoplophora glabripennis (Dubois et al. 2004). B. bassiana was previously isolated from aestivating dead H. brunneipennis in Egypt (El-Sufty et al. 1993). It is believed that the key period for managing the alfalfa weevil in Egypt, with bioinsecticides, especially the EPF, is in the late season before the last cutting in order to contaminate the adult weevils before leaving them to their aestivation sites under loose bark of the trees around the fields like eucalyptus and date palms. Under such shelters, the fungi developed on the contaminated adult weevils, infect and kill them, thus suppressing population of the active weevils in the next season.

Under the current scenario, the present study aimed to monitor larval and adult weevil population of $H$. brunneipennis before and after the application of the conidiospores of the fungus $B$. bassiana on alfalfa before the early summer cutting (April/May). The mortality of the adult weevil during their summer aestivation under the loose bark of the eucalyptus trees present around the treated field was monitored.

\section{Material and methods \\ Sampling and monitoring EAW larvae}

An alfalfa field area of $(50 \times 20 \mathrm{~m})$, located at the Agricultural Experimental Station of the Faculty of Agriculture, Giza, Egypt, was selected for the study due to its surrounding eucalyptus trees. Larvae and adults of $H$. brunneipennis were sampled, using a sweep net $(40 \mathrm{~cm}$ in diameter). Sampling was conducted in the early morning at 4 areas of the field by taking 50 double strokes left and right at $180^{\circ}$ touching the plant tops to drop them and their insect content in the net (Ali et al. 1982). Samples were collected weekly from late October (25th) to the 10th of May in seasons 2014/2015 and 2015/2016. Each sample (50 double strokes) was replicated 4 times. The catches of EAW were emptied in paper bags and transferred to the laboratory for examination. The early larval instars sampled in the plant terminals fallen in the sweeping net were examined under a stereoscope at the laboratory. Also, tapping the terminals collected by the sweeping net over a white cloth background dislodged the larvae making them better visible for counting. All the counted individuals were liberated back in the field on the same day of sampling in order not to disrupt the natural population of the weevil in the alfalfa field.

\section{Monitoring EAW adults under loose bark of eucalyptus trees}

Application of B. bassiana on the alfalfa field was carried out only once on the 25th of April in the first season 2014/2015. Monitoring of $H$. brunneipennis aestivating under the loose bark of five eucalyptus trees, located at the edge of the treated field, was done at the end of August in both seasons of the study. The loose bark of the five trees was carefully detached, and the healthy (moving) and dead weevils present were counted and mortality rate was calculated. The alive weevils were left in place, and the removed eucalyptus bark was replaced in position and fixed with two nails to keep the sheltering sites on the trees safe. The dead weevils were picked up by soft forceps and placed in $(1 \times 3$ in. $)$ glass tube plugged with a piece of cotton wool and transferred to the laboratory. The dead weevils were surface sterilized in $70 \%$ ethyl alcohol and washed by sterilized distilled water, then placed on wet filter paper in Petri dishes kept in self-clip-closing plastic bags to keep humidity and incubated at $25{ }^{\circ} \mathrm{C}$. Weevils died by $B$. bassiana infection had developed the typical "white muscardine" symptom characteristic to this fungus. Mortality rate 
induced by $B$. bassiana among the collected dead adult weevils was calculated.

\section{Production of $B$. bassiana conidia}

A local strain of the fungus, $B$. bassiana, originally isolated from a naturally infected mole cricket, Gryllotalpa gryllotalpa L., by El-Husseini et al. (2008) and identified by the Biological Control Centre at Faculty of Agriculture, Cairo University, Egypt, was propagated on Czapek's Dox agar medium composed of sucrose $20 \mathrm{~g}, \mathrm{~K}_{2} \mathrm{HPO}_{4} 1 \mathrm{~g}, \mathrm{KNO}_{3} 2$ g, yeast extract $2 \mathrm{~g}$, KCL $0.5 \mathrm{~g}, \mathrm{MgSO}_{4} 7 \mathrm{H}_{2} \mathrm{O} 0.5 \mathrm{~g}$, FeS$\mathrm{O}_{4} 7 \mathrm{H}_{2} \mathrm{O} 0.003 \mathrm{~g}$ and agar-agar $20 \mathrm{~g} / \mathrm{l}$ completed to $1 \mathrm{l}$ of distilled water and $\mathrm{pH}$ was adjusted at 5.5-6.5. The medium was autoclaved at $120{ }^{\circ} \mathrm{C}$ for $20 \mathrm{~min}$. The sterilized medium was poured into sterilized Petri dishes (12 $\mathrm{cm}$ in diameter). After cooling, the Petri dishes were inoculated by spore suspension of $B$. bassiana and incubated for 2 weeks at $25^{\circ} \mathrm{C}$. The conidiospores were harvested from the Petri dishes by scraping with a spatula and suspended in distilled sterilized water containing 0.02\% Tween 80 as the primary stock suspension according to Rombach et al. (1986). The spore count was determined by using a Neubauer hemocytometer, and the stock was kept in the refrigerator until needed. A final suspension of $\left(3 \times 10^{8}\right.$ spores $\left./ \mathrm{ml}\right)$ was prepared for field application on the alfalfa on the 10th of April 2016 and 2017 on the late afternoon by sunset to avoid exposure of the spores to the sun UV at day time. This isolate was selected for the present study due to its high virulence towards different lepidopteran, coleopteran, hemipteran and dipterteran pests in sugar beet (El-Husseini et al. 2008). Also, the commercial mycoinsecticides in Egypt are produced from this isolate due to its high virulence to many insect pests.

\section{Statistical analysis}

Mean numbers of sampled larvae and adults of EAW were rounded to complete values to show the trend of their abundance (El-Husseini et al. 2008). Comparisons of the obtained values were based on the average (mean \pm S.D.).

\section{Results and discussion \\ Larval abundance of EAW}

In both seasons, 2015/2016 and 2016/2017, the population abundance of $H$. brunneipennis larvae started from late December (December 23) to early May (May 3) recording 6 and 1 larvae, respectively (Fig. 1). The sampled number of larvae showed 2 peaks in each season. In the first season, the first peak (48 larvae/50 net double strokes) recorded was on January 10, 2016, and the second one (56 larvae/ 50 net double strokes) was on March 25, 2016. The average number of sampled larvae was $(16.07 \pm 3.53)$ in this season. The present data agree with those of Ali (1980), Ali et al. (1982) and Cook et al. (2004) for the time of weevil's appearance. In the second season (2016/17), following the application with $B$. bassiana in the former season, the larval population of H. brunneipennis showed the first peak (15 larvae/ 50 net double strokes) on January 10 and the second one on March 25 (22 larvae/50 net double strokes) with an average of $5.67 \pm 1.25$ larvae. The obtained data showed that the population abundance of EAW larvae in the second season was lower than in the first one (Figs. 1 and 2). This could be related to the application of $B$. bassiana, which suppressed the number of the active (alive) adult population survived to the following season.

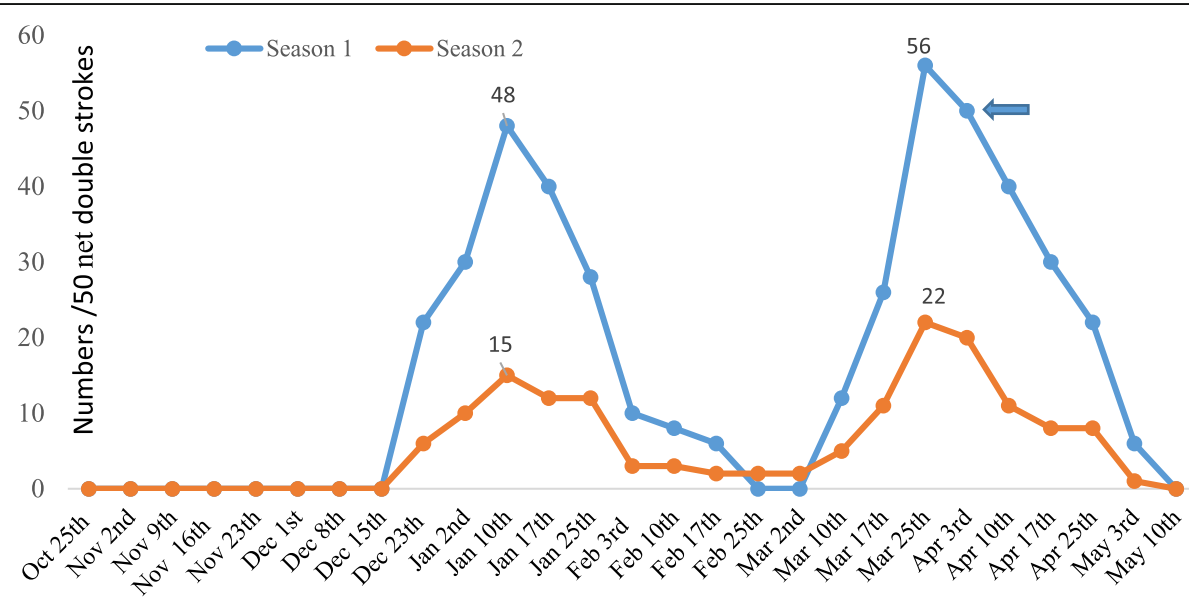

Sampling dates

Fig. 1 Numbers of H. brunneipennis (EAW) larvae/50 net double strokes in season 1 (2016/2017) and season 2 (2017/2018) after applying B. bassiana in season 1 (arrow) 


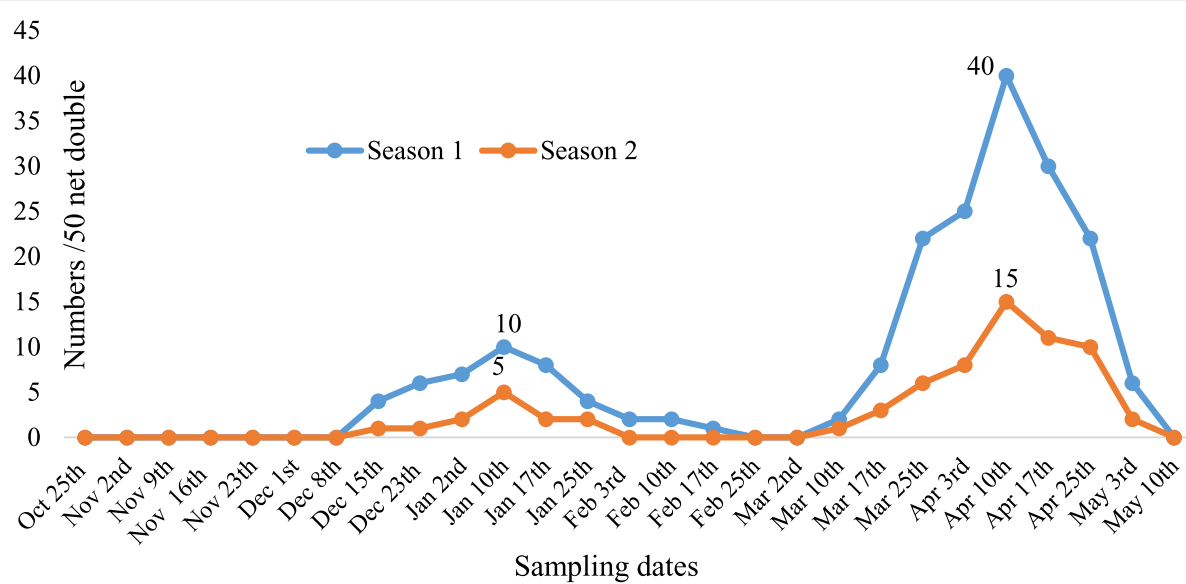

Fig. 2 Numbers of H. brunneipennis (EAW) adults/50 net double strokes in season 1 (2016/2017) and season 2 (2017/2018) after applying B. bassiana in season 1 (arrow)

\section{Adult abundance of EAW}

Abundance of the adult weevil in mid-December in both seasons of the study was recorded as 4 and 1 adults/50 net double strokes, respectively (Fig. 2). By the time, numbers of weevils peaked twice in each season. In season 2015/ 2016, the first peak (10 adults/50 net double strokes) was recorded on January 10. Meanwhile, the second one appeared on April 10 (38 adults/50 net double strokes). This result agrees with those of Ali (1980) and Ali et al. (1982). The average number of weevil adults was $7.30 \pm$ 2.03 (Fig. 2). Application of B. bassiana targeted the appearance of the second peak of adult weevil by April 10, 2016, showed its impact on the abundance of adult weevil in the second season (Fig. 2). The first peak of EAW adults in season 2016/2017 was recorded on January 10 but only with 5 weevils, while the second peak was on April 10 represented by 15 individuals. The average number of adults in season $2016 / 2017$ decreased to $2.55 \pm 0.6$ individuals compared with the previous season. It was clearly visible that the single application of $B$. bassiana targeting the second and last peak of EAW adult weevils had significantly suppressed the population of the pest in the following season. This result was supported by the numbers of collected adults aestivated under the bark of eucalyptus trees edging the treated alfalfa field in the last week of August (season 2016/2017), where out of 358 adults, 142 individuals were found dead (39.66\% mortality) and all of them developed B. bassiana fungal growth in the laboratory as shown in Fig. 3. The microscopic analysis of the dead bodies proved that the death occurred due to the applied EPF. Meanwhile, the numbers in the previous season 2015/16 were 648 and 17 for live and dead weevils, respectively, showing $2.6 \%$ natural mortality. Only 2 cadavers developed symptoms of the green muscardine of the EPF Metarhizium anisopliae (Metch.) (0.3\% natural infection) from these collected weevils. They could be previously contaminated with $M$. anisopliae conidia from soil or from the aestivating shelter under the bark of the eucalyptus trees. All the dead adult weevils in the second season died in the aestivating shelters with $B$. bassiana proved a contamination with the applied fungus in the field and not from the shelter habitat that might harbour conidia of M. anisopliae.

\section{Conclusion}

The results suggest that suppression of $H$. brunneipennis population with application of the EPF, B. bassiana, targeting the second peak of adult weevils as the last generation in the season is possible under field conditions. Such application induced a high mortality among the aestivated adult weevils with decreasing larval and adult population in the following season. Thus, repeating applications with the fungus for 3-4 successive seasons could highly suppress the pest population.

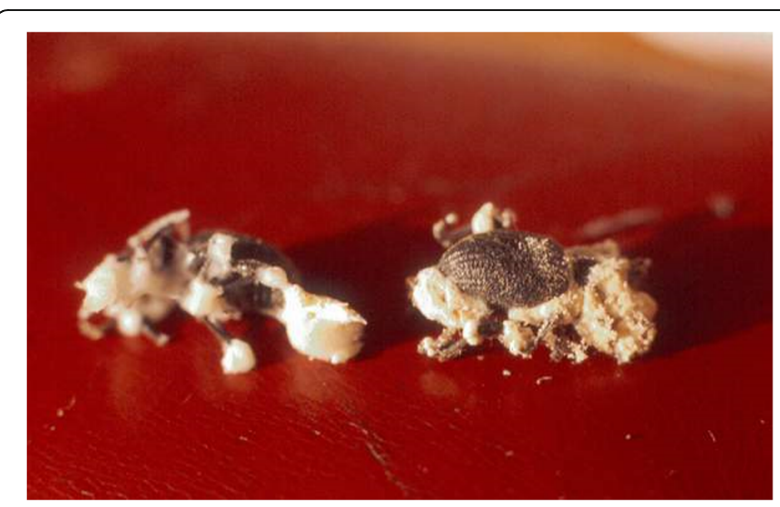

Fig. 3 Dead adults of H. brunneipennis (EAW) collected from under loose bark of eucalyptus trees post-spraying alfalfa with B. bassiana showing typical symptoms of death by "white muscardine" under humid laboratory conditions 


\section{Abbreviations}

EAW: Egyptian alfalfa weevil; EPF: Entomopathogenic fungi

\section{Acknowledgements}

Not applicable

\section{Author's contributions}

The author wrote, read, and approved the final manuscript.

\section{Funding}

This work was not supported by any funding body, but personally financed.

\section{Availability of data and materials}

All data are available in the manuscript, and the materials used in this work are of high transparency and grade.

\section{Ethics approval and consent to participate}

I agree to all concerned regulations.

\section{Consent for publication}

I agree to publish this scientific paper in the EJBPC.

\section{Competing interests}

The author declares that he/she has no competing interests.

Received: 21 July 2019 Accepted: 16 September 2019

Published online: 04 December 2019

\section{References}

Al-Azawi AF, Al-Mawlawy IMJ, Al-Mawlawy IMH (1986) Possible feeding host and feeding preference of the alfalfa weevil Hypera postica (Gyllenhal). J Biol Sci Res. 17(2):9-19

Ali AM (1980) Bionomics of the Egyptian alfalfa weevil, Hypera brunneipennis (Boheman.), with notes on its seasonal activity in Upper Egypt. Assiut J Agric Sci 11(3):77-84

Ali AM, Rizk MM, Hussein MH (1982) Ecological notes on the Egyptian alfalfa weevil Hypera brunneipennis Boheman. (Coleoptera: Curculionidae) and the associated natural enemies in the New Valley, Egypt. Assiut J Agric Sci 13(5): 179-191

Atanasova D (2012) Investigation on the pests and their entomophagous insects in multifoliolate alfalfa (Medicago sativa L.). Agriculture University Plovdiv, Department of Entomology, Bulgaria, Ph D. thesis.

Awadalla SS, AbdAllah FD, El-Serafi HAK, Badawy WBF (2014) The Egyptian alfalfa weevil Hypera brunneipennis (Boheman) as insect pest infesting some leguminous crops. Plant Prot Path Mansoura Univ 5(5):595-603

Baysal E, Atay T, Yanar Y (2018) Efficacy of some local isolates of the fungus Beauveria bassiana (Balsamo) Vuillemin on the alfalfa weevil Hypera postica (Gyllenhal) (Coleoptera: Curculionidae) larvae, under laboratory condition. Egyptian J Biol Pest Control 28:65-70

Cook K.A., Ratcliffe S.T., Grey M.E., Steffey K.L. (2004) Alfalfa weevil. https://ipm. illinois.edu/fieldcrops/insects/alfalfa_weevil.pdf. Accessed 08 Apr 2018.

Dubois T, Li Z, Hajek AE (2004) Efficacy of fibre bands impregnate with Beauveria brongniartii cultures against the Asian long horned beetle, Anoplophora glabripennis (Coleoptera: Cerambycidae). Biol Control 31(3):320-328

El Sherif SI, Tawfik MFS, El Heneidy AH (1978) The biology of the Egyptian alfalfa weevil, Hypera brunneipennis Boh. (Coleoptera: Curculionidae). Beiträge trop. Landwirtsch Veterinärmed. 16:79-89

EL-Husseini MM (1981) New approach to control the cotton leaf worm, Spodoptera littoralis (Boisd.) by Bacillus thuringiensis Berliner in clover fields. Bull Ent Soc Egypt Econ Ser 12:1-4

El-Husseini MM, Agamy EA, Mesbah AH, El-Fandary OO, Abdallah MF (2008) Using Beauveria bassiana (Bals.) Vuillemin in spraying and dusting applications for biological control of sugar beet insect pests in Egypt. Egypt Biol Pest Control 18(2):369-375

El-Mezayyen GA (2001) Field studies on the insect species on two forage crops; the Egyptian clover in Egypt and alfalfa in Libya. Egypt J Agric Res. 79(3): 923-935

El-Mezayyen GA (2003) Studies on the Egyptian alfalfa weevil, Hypera brunneipennis (Boheman) and certain associated predators in Egypt (Kafr El-Sheikh) and Libya (Sebha). J Agric Sci Mansoura Univ. 28(11):6887-6894
El-Sufty R, Boraei HA, El-Gremi S (1993) Isolation of Beauveria bassiana (Bals.) from the Egyptian alfalfa weevil, Hypera brunneipennis (Boheman) and its habitat in Egypt. J. Biol. Pest Control 3(2):149-156

Fouad M.S., Soliman M.A., Mohamed N.A. 2012. Host preference of Egyptian alfalfa weevil, Hypera brunneipennis (Bohman) (EAW) in response to different leguminous plants. Proc.13th international Conf. Agron.,Fac. Agic., Benha Univ., Egypt, 9-10 Sep., 2012, 185-194.

Imoulan A, Hussain M, Kirk PM, El Meziane A, Yao YJ (2017) Entomopathogenic fungus Beauveria: host specificity, ecology and significance of morphomolecular characterization in accurate taxonomic classification. J Asia Pac Entomol. 20:1204-1212

Mascarin GM, Jaronski ST (2016) The production and uses of Beauveria bassiana as a microbial Insecticide World J. Microbiol Biotechnol. 32:177

Mascarin GM, Kobori NN, Quintela ED, Delalibera I Jr (2013) The virulence of entomopathogenic fungi against Bemisia tabaci biotype B (Hemiptera: Aleyrodidae) and their conidial production using solid substrate fermentation. Biol Control 66:209-218

Rakha, O.M.M.A. 2008. Studies on the natural enemies of the Egyptian alfalfa weevil. M. Sc. Thesis, Fac. Agric. Kafr El-Sheikh Univ., 95 pp.

Reddy GVP, Antwi FB, Shrestha G, Kuriwada T (2016) Evaluation of toxicity of biorational insecticides against larvae of the alfalfa weevil. Toxicol Rep. 3:473-480

Rombach MC, Aguda RM, Shepard BM, Roberts DW (1986) Infection of rice brown plant hopper, Nilaparvata lugens (Homoptera: Delphacidae), by field application of entomopathogenic Hyphomycetes (Deuteromycotina). Environmental Entomology 15:1070-1073

Summers CG, Cothran WR, Coviello RL, Christensn JB (1975) Feeding damage to several leguminous and non-leguminous plants by the Egyptian alfalfa weevil. Environ Entomol. 4(6):997-1000

Vega FE, Goettel MS, Blackwell M, Chandler D, Jackson MA, Keller S, Koike M, Maniania NK, Monzo'N A, Ownley BH, Pell JK, DEN R, Roy HE (2009) Fungal entomopathogens: new insights on their ecology. Fungalecology 2:149-159

\section{Publisher's Note}

Springer Nature remains neutral with regard to jurisdictional claims in published maps and institutional affiliations.

\section{Submit your manuscript to a SpringerOpen ${ }^{\circ}$ journal and benefit from:}

- Convenient online submission

- Rigorous peer review

- Open access: articles freely available online

High visibility within the field

- Retaining the copyright to your article

Submit your next manuscript at $\boldsymbol{\nabla}$ springeropen.com 